IZA DP No. 5134

Foreign Labour Migration and the Economic Crisis in the EU: Ongoing and Remaining Issues of the Migrant Workforce in Germany

Anna Myunghee Kim

August 2010 


\title{
Foreign Labour Migration and the Economic Crisis in the EU: Ongoing and Remaining Issues of the Migrant Workforce in Germany
}

\author{
Anna Myunghee Kim \\ IZA
}

Discussion Paper No. 5134

August 2010

IZA

P.O. Box 7240

53072 Bonn

Germany

Phone: +49-228-3894-0

Fax: +49-228-3894-180

E-mail: iza@iza.org

Any opinions expressed here are those of the author(s) and not those of IZA. Research published in this series may include views on policy, but the institute itself takes no institutional policy positions.

The Institute for the Study of Labor (IZA) in Bonn is a local and virtual international research center and a place of communication between science, politics and business. IZA is an independent nonprofit organization supported by Deutsche Post Foundation. The center is associated with the University of Bonn and offers a stimulating research environment through its international network, workshops and conferences, data service, project support, research visits and doctoral program. IZA engages in (i) original and internationally competitive research in all fields of labor economics, (ii) development of policy concepts, and (iii) dissemination of research results and concepts to the interested public.

IZA Discussion Papers often represent preliminary work and are circulated to encourage discussion. Citation of such a paper should account for its provisional character. A revised version may be available directly from the author. 
IZA Discussion Paper No. 5134

August 2010

\section{ABSTRACT \\ Foreign Labour Migration and the Economic Crisis in the EU: Ongoing and Remaining Issues of the Migrant Workforce in Germany}

This paper provides an evaluation of the status of migrant workers in Germany amidst the global financial crisis. Findings of the study are drawn from the latest available data on the labour market performance of native-German and non-German migrant workers as well as other socioeconomic integration measures of the receiving state. Compared to the experience of migrants in most of the major receiving states of the $E U$, the status of the predominantly low-skilled sector-employed migrant workers in Germany, where primarily the skilled-workforce concentrated industries of high-value products is affected, has remained unchanged during the crisis. On the other hand, marginalisation of the ethnic and national minority population appears to be a persistent phenomenon marked by long-standing labour market exclusion. This is manifested in over two decades of double-digit unemployment rates of the foreign migrant population in the former 'guest-worker' importing country. This implies for the economy the need to settle long-term problems and implement strategies towards a better labour market integration of the minority migrant population beyond the recent recession.

JEL Classification: F22, J61, O15

Keywords: global financial crisis, low-skilled sector, migrant workers, guest-workers, labour market integration, minority migrant population

Corresponding author:

Anna Myunghee Kim

IZA

P.O. Box 7240

D-53072 Bonn

Germany

E-mail: akim@iza.org 


\section{Introduction}

Since the European Union (hereafter EU) fell into a steep recession in the second half of 2008, migration has once again emerged as one of the heated issues of debate in Europe. The EU's growing concern over people on the move has two main reasons:1) the EU, under the European Community's Treaty of Free Movement of Workers, has the largest internal (intraregional) migrant workforce after the United States, which is currently estimated at 14 million of the total 43 million foreign-born individuals in the EU-27 (Eurostat 2008, Muenz 2008, Rossi, Burghart 2009), 2) the foreign-born migrant population of the EU is concentrated in the low-skilled, tertiary industry sectors of the host economies and believed to be most vulnerable to the effects of the recent economic crisis.

Germany is considered to be a particularly interesting and important case of a receiving country amongst the Member States due to its long-standing central position in the geopolitics, and the economy of Europe. Despite being a "reluctant land of immigration" (Brubaker 1992), post-war Germany has been one of the top destination countries in Europe for millions of deprived people from both the south and the east.

This country report on Germany has been prepared to provide a mid-crisis evaluation of the status quo of migrants and foreign labour migration policies in Germany amidst the global economic downturn. Given the short temporal dimension to the query, key findings of the study are drawn from the latest available descriptive statistics on the German labour market and the population data that spans the years 2008 and 2009. While the primary aim of the paper is to address recent recession-driven problems of migration, it also touches upon more long-standing issues, and challenges that are related to integration and equal opportunity policies in the country. Integration-related issues are considered to have significant policy implications at both the national and the EU policy level beyond the financial crisis.

\section{Background}

Considering migrant workers in an economic crisis indeed raises a plethora of issues that include changes both in actual patterns and policies of labour migration, and the impacts on the labour market, as well as a rise in xenophobia. All of these prevailing problems during a 
recession ultimately lead to one central question: What are the long- and short-term implications of the external shock for the migrants, and the policies of the receiving country?

Recent statistics on the German experience with respect to its labour market make a clear point against the generic claims that have been made against the labour market and migrant workers in the Member States since the outbreak of the global and regional (Eurozone) economic crisis.

It has been commonly assumed by the media that foreign workers in Europe, particularly those more recently migrated from the post-2004 accessed member states of Eastern Europe who have settled in the once booming and liberal economies of the EU such as the UK and Ireland, have been the foremost victims of the crisis as they have become the first to be laid off and consequently homeless amidst the recession (BBC NEWS, February 23 2008). In quite contrast to its counterpart economies of the EU-15, an extremely grim scenario has not been observed in the German labour market. According to the German Federal Agency for Employment (hereafter BA), there was only a 0.8 percentage point increase in unemployment rates among the foreign migrant workforce employed in jobs that are subject to social security payments during the peak period of the crisis, from 15.8 percent in September 2008 to 16.6 percent in September 2009. Quite similarly, an increase in the unemployment rate among the native German workforce remained at a very low level during the same period, from 7.1 percent to 7.5 percent (BA 2009).

Yet, this relative employment and unemployment stability of migrant workers in the host economy during the recession is not conclusive of the fact that migrants in Germany are better integrated into the host society than those living elsewhere in the EU. In the German case, long-term failings in the integration of its migrant minority population has been most notably seen in the double-digit gap in the unemployment rates between the migrant workforce and the native workforce over the past decade. It also appears to be far more significant and challenging than problems driven by the recent economic recession. In fact, surges in unemployment and the return movement of migrant workers, which have been highlighted elsewhere such as in the UK and Spain since mid-2008, have not been observed in Germany. 


\section{The political and legal context of international migration to Germany}

Understanding the situation of foreign migrant workers in Germany essentially requires an understanding of the very complex legal and political framework of the country's immigration system.

Under the guest-worker system in the post-war economic miracle era, Germany has received over one million 'guest workers' from then labour-surplus economies of Mediterranean Europe. The second migration wave consisted of people from the former soviet block. It was during the post-socialist period - 1991-1999- in which Germany once again emerged as the top destination country for nearly three million newcomers that include two million ethnic Germans form Russia, and hundreds and thousands of political refugees from Eastern Europe.

Given the early mass influx of people from Mediterranean Europe, and the former Soviet Union, Germany has been seen as an established immigration country in Europe. The reality, in terms of the immigration policy development of the state, is however quite the opposite: politically and legally Germany began to change from a temporary, guest worker system to an active immigration system only in less than a decade, starting from a reform in the country's naturalisation law in 2000. Indeed as the American immigration scholar Cornelius (2004) puts it, Germany is one of the "late-comers to immigration" along with the other post-1990 emerged immigration nations of the OECD member economies (Italy, Spain, Japan, and South Korea).

In contrast to the former laws for foreigners (Auslaendergesetz) that had primarily served as an administrative management instrument of its guest worker settlers, the Zuwanderdungsgesetz that came into effect in 2005 serves as the country's 'first' fullyfledged, modern immigration law. The foremost difference between the old law and the new law of immigration is that the new one recognises the need for an active integration of both the former guest workers and prospective permanent migrants into the economy and the society.

The introduction of the modern immigration law has resulted in substantial revisions to the migration-related policies of the country over the past five years. Yet at the international level, many of the significant changes that have been made over the last few years remain under-explored. This is largely owed to the high complexity of the German legal system 
which has often been the source of inaccurate interpretations either by oversimplifications or misleading translations of the varying migrant-related legislations regulated at the federal, and the state (Laender) levels.

One of the key issues that has been often excluded from the cross-national comparative analysis is the differentiation of the intricate de-jure, and de-facto status of Germany's minority immigrant population. Although the new German nationality law enacted on 1.1.2000 allows the granting of German citizenship via jus soli or birthplace principle, 1.7 million members of native-born ethnic minority populations in Germany remain under foreign national status. One of the major reasons for the low rate of German citizenship among second- and third-generation immigrants from non-EU countries is attributed to the limited jus soli practice of the German nationality law. While accepting the birthplace principle, the post-2000 law which created the so-called 'option model' German nationality legislation strictly bans dual citizenship and requires German-born children of immigrants to choose a single citizenship when they reach age 18. This has been widely criticised of putting too much pressure on native-born immigrant youths' decision-making on their nationality since the majority of immigrant descendants have to give up either their German nationality (citizenship of their adopted homeland), or the nationality of their parents (citizenship of their ethnic homeland). Pressure on the latter has been particularly pertinent to the individuals of Muslim family background which has held back the integration of the Muslim ethnic minority communities into German society.

\section{Migrants (Migranten) and versus Foreigners (Auslaender)}

The seemingly simple and commonly understood term of "migrants” for aliens, which is known as "Migranten" in German is a rather new and unsettled concept in the German context. Until the new immigration law was created in 2005, the public had not been fully aware of words like 'migrants; and 'immigrants'. Instead, every person belonging to an ethnic minority community in Germany was considered and called a foreigner "Auslaender” in German, regardless of the migrant individual's citizenship and settlement status within the host society. This primarily owes to the country's strong ethnonational identification (citizenship), which is embedded in the long practice of the jus sanguinis nationality policy and the traditionally limited access to German citizenship for members of an ethnic minority. 
The term migrants began to be used officially in the country's population census followed by the introduction of the nation's first immigration law in 2005. The latest population census (Mikrozensus 2007) uses the German “Migranten” for migrants instead of the previously used term "Auslaender". This allowed a broader inclusion of ethnic minorities in the country's official statistics. Ever since the conceptual revision of the population census, migrants in German official statistics now commonly cover not only the 7.3 million de-jure foreign nationals, but also another 8.1 million combined for both foreign-born and native-born minority population of the country, which includes those who have either a direct or an indirect international migration background (either by being foreign-born or having a foreignborn parent respectively). According to the new census definition of migrants, those individuals with a migrant background, known as "Menschen mit Migrationshintergrund" in German, make up nearly 20 percent of the total German population. This migrant population includes nearly five million "native-born”, second- and third- generation immigrants, who account for more than half of the German national individuals, and one-third of the total migrants in Germany (see Table 1, and Figure 1).

Table 1 Immigrants in the new German population census

\begin{tabular}{|c|c|c|c|}
\hline \multicolumn{4}{|c|}{$\begin{array}{c}\text { Migrants (individuals with a migration background) } \\
15.4 \text { million } \\
\text { (out of total } 82.3 \text { million population of Germany) }\end{array}$} \\
\hline \multicolumn{2}{|c|}{$\begin{array}{l}\text { German citizens } \\
8.1 \text { million } \\
\end{array}$} & \multicolumn{2}{|c|}{$\begin{array}{c}\text { Non-German citizens } \\
\text { (the de-jure foreign population) } \\
7.3 \text { million }\end{array}$} \\
\hline $\begin{array}{l}\text { Individuals with own } \\
\text { migration background } \\
\text { (foreign-born) }\end{array}$ & $\begin{array}{c}\text { Individuals without own } \\
\text { migration background } \\
\text { (native-born) }\end{array}$ & $\begin{array}{l}\text { Individuals with own } \\
\text { migration background } \\
\text { (foreign-born) }\end{array}$ & $\begin{array}{c}\text { Individuals without own } \\
\text { migration background } \\
\text { (native-born) }\end{array}$ \\
\hline 4.9 million & 3.2 million & 5.6 million & 1.7 million \\
\hline
\end{tabular}

Source: Mikrozensus 2007

Despite the terminological alteration, the change does not effectively categorise the national population by birth place; it only replaces the ethnic origin-based, narrow definition of a foreigner.

In practice the new German census definition of “migrants” specifies populations that are primarily based on ethno-national origin. Migrants used in the German context thus include "those with own migration background who are first-generation immigrants to Germany 
having made the move themselves", and also "those without their own migration history, but have ancestors immigrated to Germany”. This categorisation defined by the new German immigration law, and population census reflects a combination of both jus sanguinis (citizenship right by blood), and jus soli (citizenship right by place of birth) approaches which is in turn is not equivalent to the international (OECD) standard definition of 'foreign-born population' that solely draws from the jus soli principle for categorising immigrant populations.

Thus, if one were to employ the international standard of immigrant categorisation, Germany's foreign-born (immigrant) population consists of by 10.5 million individuals (see Table 1 and Figure 1).

Figure 1 Share of each ethnic and national minority group in Germany's total migrant population

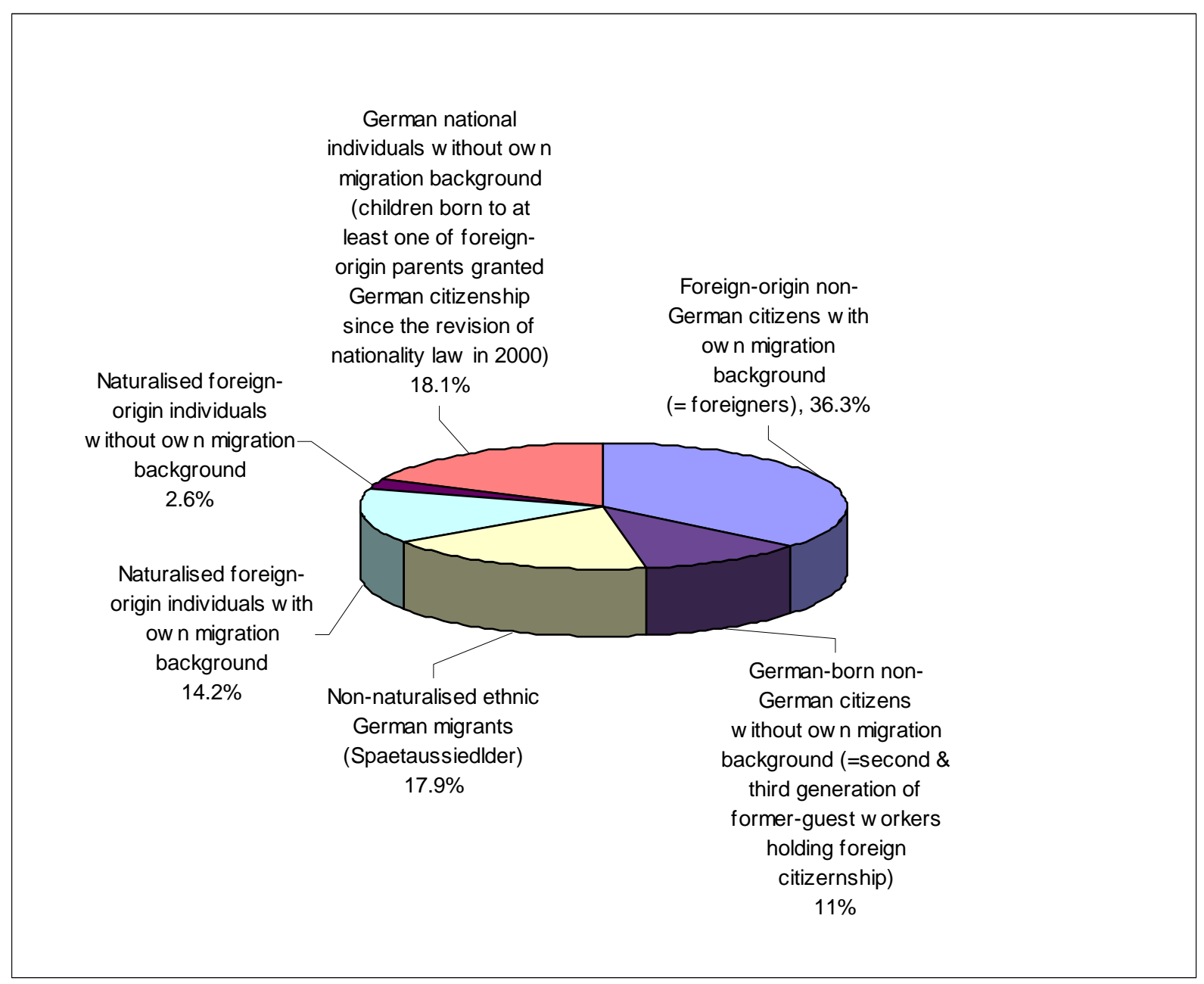

Source: German microcensus (2007) et al. Federal Office for Migration and Refugees (2009) 
In general, the Microcensus and the Federal Statistical Office, which are two of the key authorities for generating and analysing data on the nation's population, employ the broad definition of migrants. In contrast, the Central Registrar of Foreigners and the BA stick to the narrower categorisation of foreign national residents. For example, unless stated as an exception, analyses of the labour market performance of immigrants and their presence in the state's social security system provided by the two governmental agencies are limited to nonGerman citizens.

Thus, although this broader categorisation of the migrant population in the new census serves to better analyse the status of approximately 2.8 million German descendants from the Soviet Union who were granted German citizenship by return law of the state, but perceived as an immigrant minority group in the host society, the new definition of "migrants" in the population statistics, and the public debate over immigrants in the country is widely open to scrutiny.

In this study, unless otherwise stated, the terms "migrant population", or "migrant individuals” are used in the broad context of immigrants as defined by the German population census referring to all ethno-national minority-origin people of the country regardless of their citizenship status. By contrast, using “foreign migrant population" or "foreign migrant workers" straightforwardly denotes the de jure non-German workforce, as used in the labour market performance-related analysis of the BA.

\section{Data and profiles of immigrants in recent-day Germany}

Post-2000 statistics on migration of populations into Germany indicate a number of key features of migration and migrants in the country which paints a dominant picture of the socio-economic and urban development trajectories of migrant populations in the country.

First, Turkish-origin migrants who are widely believed to make up the absolute majority of the foreign population of Germany, decreased by 0.4 percent from 2004 to 2008, while migration from EU-10 countries has increased by 28.2 percent in the same period. According to the latest population census, Turks account for 16.4 percent of the total 15.3 million individuals having international migration background in Germany, while they make up 25.1 percent of total foreign national residents in the country (see Microcensus 2007, et al. Federal Statistical Office 2008b). 
Second, European nationals including individuals from the former Soviet Union and the Central \& Eastern European Countries (CEECS), excluding Turks, account for nearly 40 percent of the total migrant population in Germany, while they make up more than the half (55 percent) of the entire foreign national residents. In turn, the entire migrant population of Germany is dominantly of European origin, and thus not as ethnically diverse as it has been widely assumed. Individuals of Southeast Asian and African-origin make up only 6. 7 per cent of the country's total migrant population (see Tables 2 and 3). 
Table 2 Migrant stock in the German population census

\begin{tabular}{|c|c|c|c|c|c|c|c|}
\hline \multirow{3}{*}{\multicolumn{2}{|c|}{ Place of origin/region }} & \multicolumn{4}{|c|}{$\begin{array}{l}\text { Migrant population in Germany } \\
\text { (Migranten): Individuals having an } \\
\text { international migration background }\end{array}$} & \multirow{2}{*}{\multicolumn{2}{|c|}{ Total }} \\
\hline & & \multicolumn{2}{|c|}{$\begin{array}{c}\text { Individuals with } \\
\text { own migration } \\
\text { background }\end{array}$} & \multicolumn{2}{|c|}{$\begin{array}{l}\text { Individuals without } \\
\text { own migration } \\
\text { background }\end{array}$} & & \\
\hline & & $\begin{array}{l}\text { Number in } \\
\text { thousand }\end{array}$ & in $\%$ & $\begin{array}{l}\text { Number in } \\
\text { thousand }\end{array}$ & in $\%$ & $\begin{array}{c}\text { Number in } \\
\text { thousand }\end{array}$ & in $\%$ \\
\hline \multicolumn{2}{|l|}{ EU-27 } & 2.545 & 69 & 1.141 & 31 & 3.686 & 23.9 \\
\hline \multirow[t]{4}{*}{$\begin{array}{l}\text { Among } \\
\text { which: }\end{array}$} & Greece & 240 & 62.5 & 144 & 37.5 & 384 & 2.5 \\
\hline & |taly & 431 & 56.6 & 330 & 43.4 & 761 & 4.9 \\
\hline & Poland $^{1}$ & 529 & 82.9 & 109 & 17.1 & 638 & 4.1 \\
\hline & Romania $^{1}$ & 207 & 86.3 & 33 & 13.8 & 240 & 1.6 \\
\hline \multicolumn{2}{|c|}{ Other Europe } & 3.327 & 69.1 & 1,486 & 30.9 & 4,813 & 31.2 \\
\hline \multirow[t]{9}{*}{\begin{tabular}{|l|} 
Among \\
which:
\end{tabular}} & \begin{tabular}{|l} 
Bosnia- \\
Herzegovina
\end{tabular} & 217 & 76.7 & 66 & 23.3 & 283 & 1.8 \\
\hline & Croatia & 251 & 67.3 & 122 & 32.7 & 373 & 2.4 \\
\hline & \begin{tabular}{|l} 
Russian \\
Federation $^{1}$
\end{tabular} & 510 & 90.9 & 51 & 9.1 & 561 & 3.6 \\
\hline & Serbia & 287 & 73.4 & 104 & 26.6 & 391 & 2.5 \\
\hline & Turkey & 1.511 & 59.8 & 1,016 & 40.2 & 2,527 & 16.4 \\
\hline & Ukraine & 192 & 89.3 & 23 & 10.7 & 215 & 1.4 \\
\hline & Europe total & 5.872 & 69.1 & 2.627 & 30.9 & 8.499 & 55.1 \\
\hline & Africa & 342 & 71.3 & 138 & 28.8 & 480 & 3.1 \\
\hline & America & 233 & 67.3 & 113 & 32.7 & 346 & 2.2 \\
\hline \multicolumn{2}{|l|}{\begin{tabular}{|l} 
Asia, \\
Australia, \\
Oceania
\end{tabular}} & 1.183 & 78.8 & 318 & 21.2 & 1,501 & 9.7 \\
\hline \multirow[t]{3}{*}{\begin{tabular}{|l} 
Among \\
which
\end{tabular}} & $\begin{array}{l}\text { Near and Middle } \\
\text { East }\end{array}$ & 584 & 82.5 & 124 & 17.5 & 708 & 4.6 \\
\hline & Kazakhstan $^{1}$ & 203 & 94.4 & 12 & 5.6 & 215 & 1.4 \\
\hline & $\begin{array}{l}\text { South and } \\
\text { Southeast Asia }\end{array}$ & 416 & 74 & 146 & 26 & 562 & 3.6 \\
\hline \multicolumn{2}{|c|}{ Not specified } & 2.904 & 63.3 & 1,682 & 36.7 & 4.586 & 29.8 \\
\hline \multicolumn{2}{|c|}{$\begin{array}{l}\text { Total individuals with } \\
\text { international migration } \\
\text { background }\end{array}$} & 10.534 & 68.4 & 4.877 & 31.6 & 15.411 & 100.0 \\
\hline \multirow{8}{*}{\begin{tabular}{|l|} 
Among \\
which
\end{tabular}} & Foreign nationals & 5.592 & 76.8 & 1.688 & 23.2 & 7.280 & 47.2 \\
\hline & German nationals & 4.942 & 60.8 & 3.189 & 39.2 & 8.131 & 52.8 \\
\hline & \begin{tabular}{|l} 
Spaetaussiedler \\
ethnic German \\
migrants from \\
Eastern Europe \\
granted German \\
citizenship²
\end{tabular} & 2.756 & & - & & 2.756 & 17.9 \\
\hline & from Poland & 518 & & & & 518 & 3.4 \\
\hline & $\begin{array}{l}\text { from the Russian } \\
\text { Federation }\end{array}$ & 475 & & & & 475 & 3.1 \\
\hline & from Kazakhstan & 320 & & & & 320 & 2.1 \\
\hline & from Romania & 173 & & & & 173 & 1.1 \\
\hline & $\begin{array}{l}\text { from the former } \\
\text { Soviet Union }\end{array}$ & 137 & & & & 137 & 0.9 \\
\hline
\end{tabular}

Source: Microcensus 2007 et al. Federal Statistical Office 2008b.

1) Without ethnic German migrants (Spaetaussiedler), ${ }^{2)}$ No identification of place

of origin was possible for app. one million ethnic German migrants 
Table 3 Foreign population in Germany by immigration status and selected nationalities

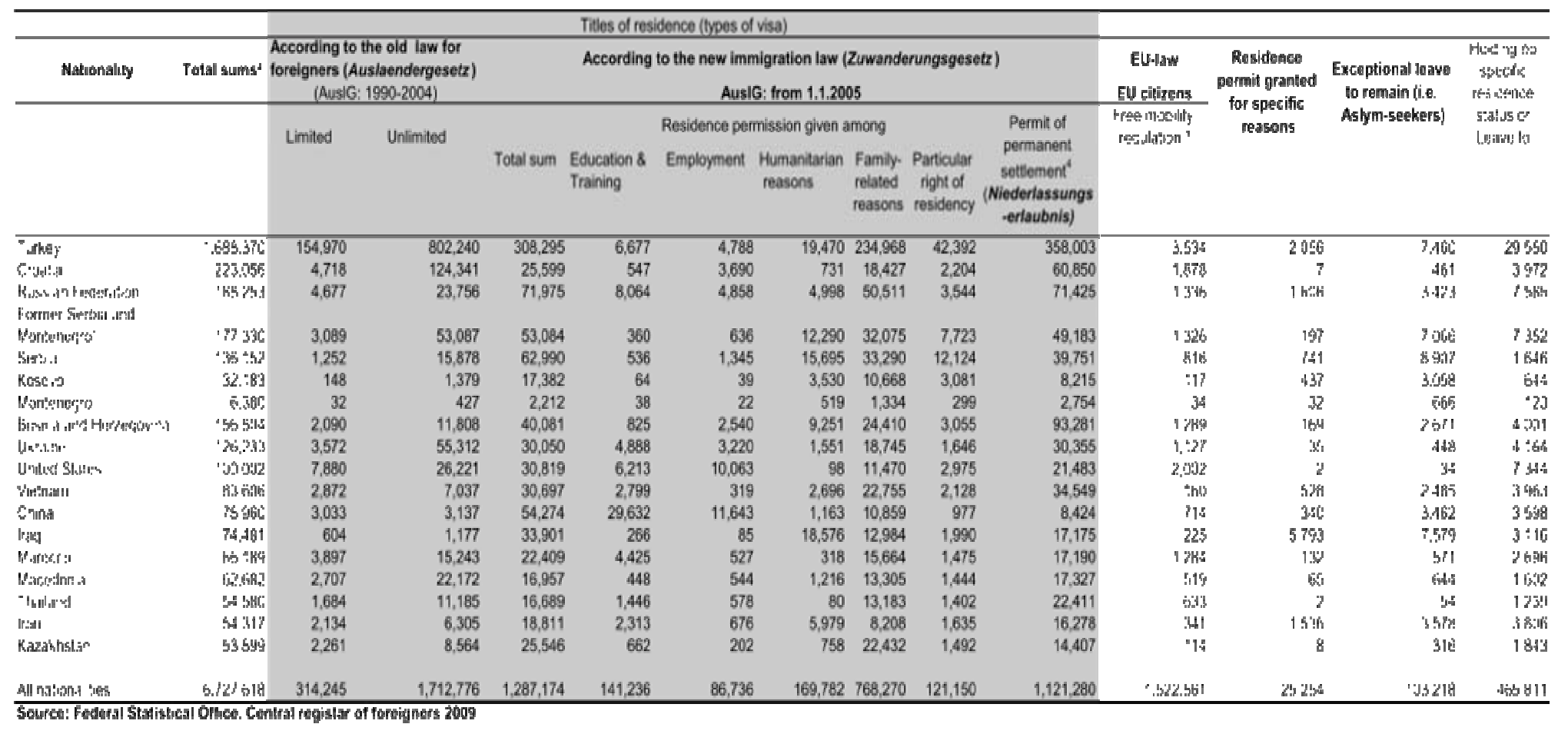

A

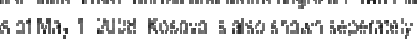

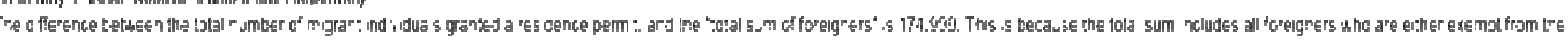

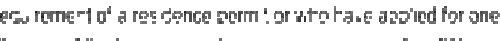

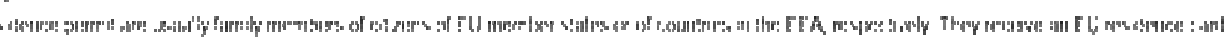

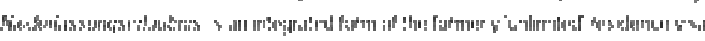

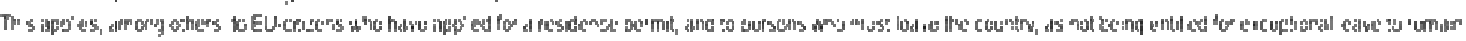


Third, the vast majority of Germany’s foreign migrant population is comprised of post-WWII guest worker migrant settlers from Southern Europe who have lived in the country for an average of 18.2 years (or 20 years when considering the total number of people who originated from foreign countries). In turn, Germany’s migrant residents are getting old too. The gender distribution is quite even. The male-to-female ratio of foreign migrant population is 51.2:48.8 (Central Registrar of Foreigners 2009 et al. Federal Statistical Office).

Fourth, the migrant population in Germany has traditionally been marginalised in the mainstream society. This is evidenced by the dominant low-income status of the average migrant population, thus invoking their prevalent reliance on the state's minimum income support for the long-term unemployed known as Hartz IV in German. The Hartz IV, formally known as Social Security Code II is a revised form of means-tested minimum security benefits which was introduced in 2005 for the individuals who are out of labour market, but recognised as "active job-seekers". The share of minority migrants among the total recipients of the non-contributory social security benefits has significantly increased, which currently accounts for 21 percent (Federal Ministry for Labour and Social Affairs 2009).

Although currently part-time foreign national workers account for less than 20 percent of the total foreign workforce in Germany's formal labour market (BA 2009c), more than a quarter of foreign migrant workers in the country were reported to be living below the poverty line in 2005, a year that is considered to be a time of economic boom in the country (see Table 4). 
Table 4 Economic status of the migrant population by income level

\begin{tabular}{|c|c|c|c|c|c|c|c|c|c|c|}
\hline & & \multirow{3}{*}{ Gender } & \multirow{3}{*}{ Population in thousands } & \multicolumn{2}{|c|}{ Among them } & \multicolumn{5}{|c|}{ Migrant workforce by gross income levels } \\
\hline & & & & $\begin{array}{c}\text { With a stated } \\
\text { household } \\
\text { income level } \\
\text { in } \%\end{array}$ & $\begin{array}{l}\text { *Below the } \\
\text { poverty- } \\
\text { risk- } \\
\text { threshold }\end{array}$ & $\begin{array}{c}\text { Of the total } \\
\text { civilian } \\
\text { workforce }\end{array}$ & $\begin{array}{l}\text { Up to } \\
1,099 \\
\text { euros }\end{array}$ & $\begin{array}{c}1,100 \text { to } \\
1,999 \\
\text { euros }\end{array}$ & $\begin{array}{c}2,000 \text { to } \\
3,199 \\
\text { euros }\end{array}$ & $\begin{array}{l}\text { 3,200 euros or } \\
\text { more }\end{array}$ \\
\hline & & & & $\%$ & $\%$ & $\%$ & $\%$ & $\%$ & $\%$ & $\%$ \\
\hline \multirow{3}{*}{\multicolumn{2}{|c|}{$\begin{array}{l}\text { All foreign-origin (migrant) } \\
\text { population }\end{array}$}} & male & 7,795 & 93.6 & 27.9 & 43.0 & 28.7 & 49.9 & 16.5 & 4.9 \\
\hline & & female & 7,538 & 93.9 & 28.5 & 32.5 & 66.8 & 28.0 & 4.1 & 1.1 \\
\hline & & total & 15,333 & 93.7 & 28.2 & 37.9 & 44.8 & 40.6 & 11.2 & 3.3 \\
\hline \multirow{9}{*}{ 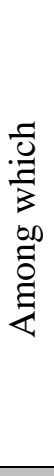 } & \multirow{3}{*}{$\begin{array}{l}\text { Spaetaussiedler (ethnic German } \\
\text { migrants) }\end{array}$} & male & 1,995 & 94.5 & 20.0 & 45.8 & 25.7 & 55.2 & 15.8 & 3.3 \\
\hline & & female & 2,058 & 94.5 & 21.3 & 37.9 & 67.3 & 28.5 & 3.2 & 1.0 \\
\hline & & total & 4,053 & 94.5 & 20.7 & 41.7 & 44.9 & 42.9 & 10.0 & 2.2 \\
\hline & \multirow{3}{*}{$\begin{array}{l}\text { German-born, and naturalised } \\
\text { migrant individuals }\end{array}$} & male & 1,992 & 93.9 & 24.4 & 33.7 & 30.0 & 45.3 & 19.1 & 5.6 \\
\hline & & female & 1,967 & 94.1 & 25.0 & 26.7 & 63.1 & 30.6 & 5.1 & 1.2 \\
\hline & & total & 3,959 & 94.0 & 24.7 & 30.3 & 44.5 & 38.9 & 13.0 & 3.6 \\
\hline & \multirow{3}{*}{$\begin{array}{l}\text { Foreign-born (foreign national) } \\
\text { migrant individuals }\end{array}$} & male & 3,809 & 92.9 & 34.0 & 46.5 & 29.8 & 48.9 & 15.8 & 5.5 \\
\hline & & female & 3,512 & 93.4 & 34.7 & 32.7 & 68.2 & 26.4 & 4.2 & 1.2 \\
\hline & & total & 7,321 & 93.1 & 34.3 & 39.8 & 44.9 & 40.1 & 11.3 & 3.8 \\
\hline \multirow{3}{*}{\multicolumn{2}{|c|}{ Total }} & male & 40,339 & 92.5 & 14.3 & 47.1 & 23.0 & 43.9 & 23.1 & 10.0 \\
\hline & & female & 42,127 & 92.2 & 15.2 & 37.3 & 56.3 & 34.3 & 7.6 & 1.8 \\
\hline & & total & 82,465 & 92.3 & 14.8 & 42.1 & 38.1 & 39.5 & 16.1 & 6.3 \\
\hline
\end{tabular}


Source: Federal Statistical Office; special evaluation of the Mikrozensus 2005 provided for the Federal Government Commissioner for Migration, Refugees, and Integration.

*Persons considered as being at the poverty line, if their per-capita net-income is less than $60 \%$ of the average income (median). The per-capita income is weighted according to the number of household members. In order to do so, the household net income is referenced to the weighted number of household members. The household's main breadwinner is assigned a value of 1 , all household members who are 14 years of age or over are assigned values of 0.5 and all those younger than 14 are weighted with a value of 0.3 (OECD-equivalent scale). Due to missing data, $7.7 \%$ of the population were not considered in income calculations. Equivalence incomes and poverty quotas from the Mikrozensus were calculated according to the evaluation of Stauder/Hüning 2004: Statistische Analysen und Studien NRW, Vol. 13. 
Table 5 Share of foreign migrant workforce with social insurance in the total German workforce by sector

\begin{tabular}{lcc}
\hline Sector & Number & $\begin{array}{c}\text { Share in the total workforce } \\
(\%)\end{array}$ \\
\hline Manufacturing & 542,760 & 8.2 \\
Business-related services including & & \\
consultancy & 288,366 & 8.5 \\
Retailing, Maintenance, and Repairing of & 223,406 & 5.7 \\
vehicles & 161,509 & 21.4 \\
Catering, and Tourist industry & 130,090 & 4.2 \\
Health, and Social care services & 115,265 & 7.1 \\
Transportation, and Communication & 98,028 & 6.4 \\
Construction & 71,673 & 6.1 \\
Other services & 43,682 & 4.5 \\
Education, and Teaching & 31,928 & 1.9 \\
Public administration & 30,018 & 9.8 \\
Agriculture, Forestry, Fishing & 23,943 & 2.4 \\
Banking, and Insurance & 6,624 & 6.3 \\
Mining, Energy, Recycling, & 4,285 & 11.9 \\
Domestic labour & $1,771,577$ & \\
Total number of workforce (with social & & \\
insurance) & &
\end{tabular}

Source: BA (2006)

According to Table 5, nearly half of the foreign migrant workforce is employed in the labour-intensive and low-waged primary and tertiary industries of the German economy, including agriculture and forestry. However, the domestic labour sector however remains highly tricky, because the figure for the regular full-time and parttime jobs covered by the statutory social insurance does not include the undocumented (e.g. cleaners and nannies working illegally in private households), and those in socalled "mini-jobs", meaning short-term jobs with small payments. Mini-job takers are officially categorised as unemployed due to their short working hours and low wages (i.e., less than 15 hours/week, 400 Euro/month), and hence are not subject to the statutory social security payments. According to recent official statistics, foreigners make up 13.4 percent of the registered mini-job workers in the domestic labour sector, while the native workforce in the sector accounts for 86.6 percent (Mini-job center of German statutory pension insurance 2009). However, whether these figures provide a realistic picture of the migrant workforce in the sector is a subject of speculation since millions of middle class German households are believed to be using unregistered and 
low-cost cleaner's services originating predominantly from low-income economies of Europe such as Poland, Bulgaria, and Turkey. An unofficial count of the number of such informal foreign domestic workers in Germany ranges from 1.2 million to 2.9 million (Focus 2004). Whatever the actual number would be, workers in this sector and the service industry as a whole in the German economy are not considered to have been affected by the recent crisis, and are not particularly relevant to the study.

Workers in jobs that are subject to statutory social security payments (e.g. health insurance, long-range nursing care, pensions and unemployment insurance) make up the vast majority of the total employed population in the German economy, accounting for nearly 70 percent of the 40.55 million civilian workforce of the country (BA 2009c). The remaining 30 percent of the total workforce, which is exempt from the statutory social security payments (social insurance) in the economy, includes those self-employed and civil service officials who are predominantly native Germans.

\section{International migration trajectories in post-1990 Germany}

Net-migration into Germany has been, as a whole, fluctuating for nearly two decades, starting in the early 1990s. The End of the Soviet Era entailed an exodus of people from Eastern to Western Europe as well as transatlantic movement. According to Figure 2, one can see a clear spike in migration influx during that particular period, which has gradually decreased since the mid-1990s.

Since 2000, one observed a downward trend in net migration: a tendency towards negative growth of net migration into the country indicated by a decreasing gap between in-migration to the country and out-migration from the country both among the native and foreign population of the country. These trends have not really changed in the last few years including 2009, which was considered to be economically the most turbulent time in post-war Europe (see Figures 1 and 2).

The fluctuating nature of net-migration, particularly among foreigners in recent Germany, may be due to the growing volume of intra-regional migration particularly through a massive influx of people from the EU-12 countries to Germany which 
increased by more than 30 percent on average between 2007 and 2008. The increase of total international migration into the country in the same period remained at only 0.2 percent (Federal Statistical Office 2009 et al. Central Registrar of Foreigners 2009). Given the geographical proximity, the intra-European Union movement involves more fluid and circular mobility of labour rather than long-term or permanent migration, which may also contributed to the shaping of the fluctuating trend of recent netmigration to Germany. 
Figure 1 Net-migration to Germany in recent economic crisis (intra-Europe mobility comparison)

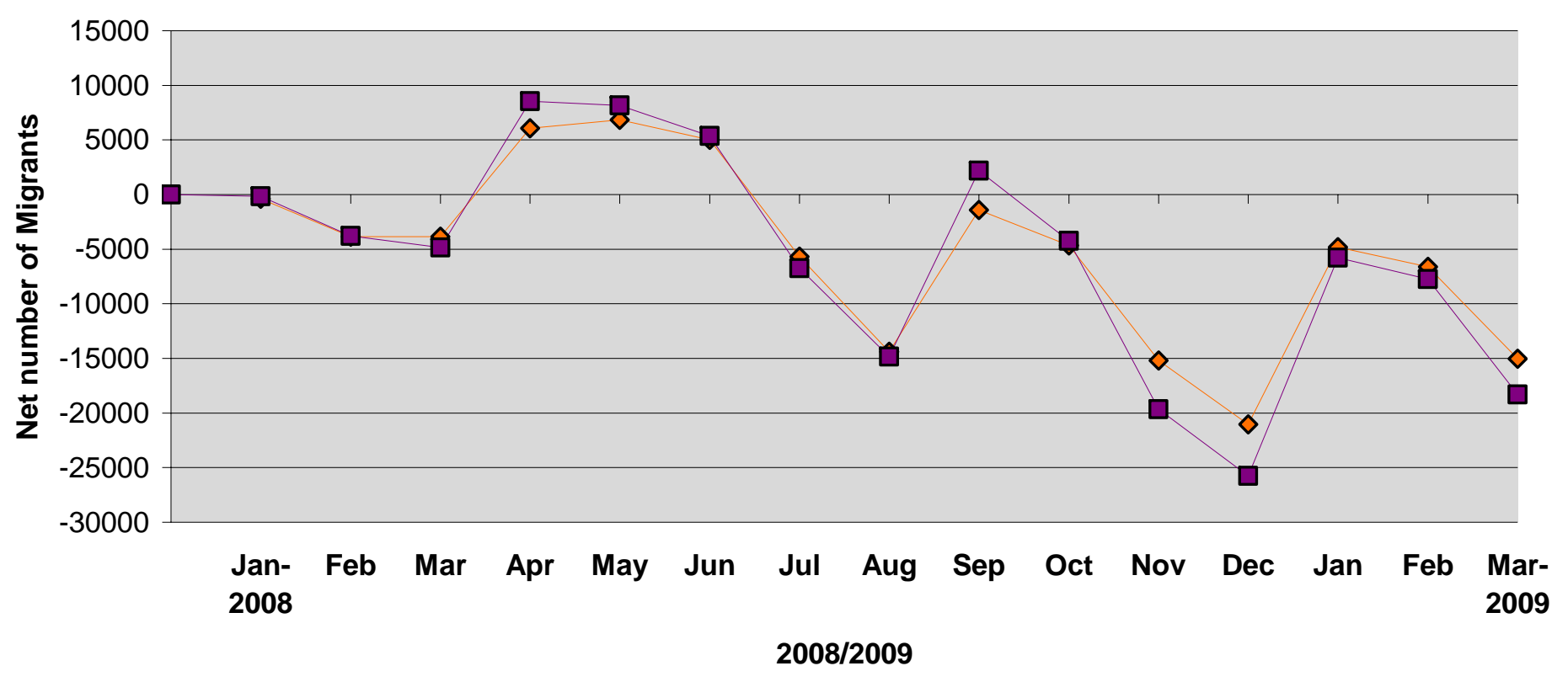

$\diamond$ Europe (EU+ Non-EU)

$\square$ - Total

Source: Federal Statistical Office 2009 
Figure 2 Net-migration to Germany in recent economic crisis

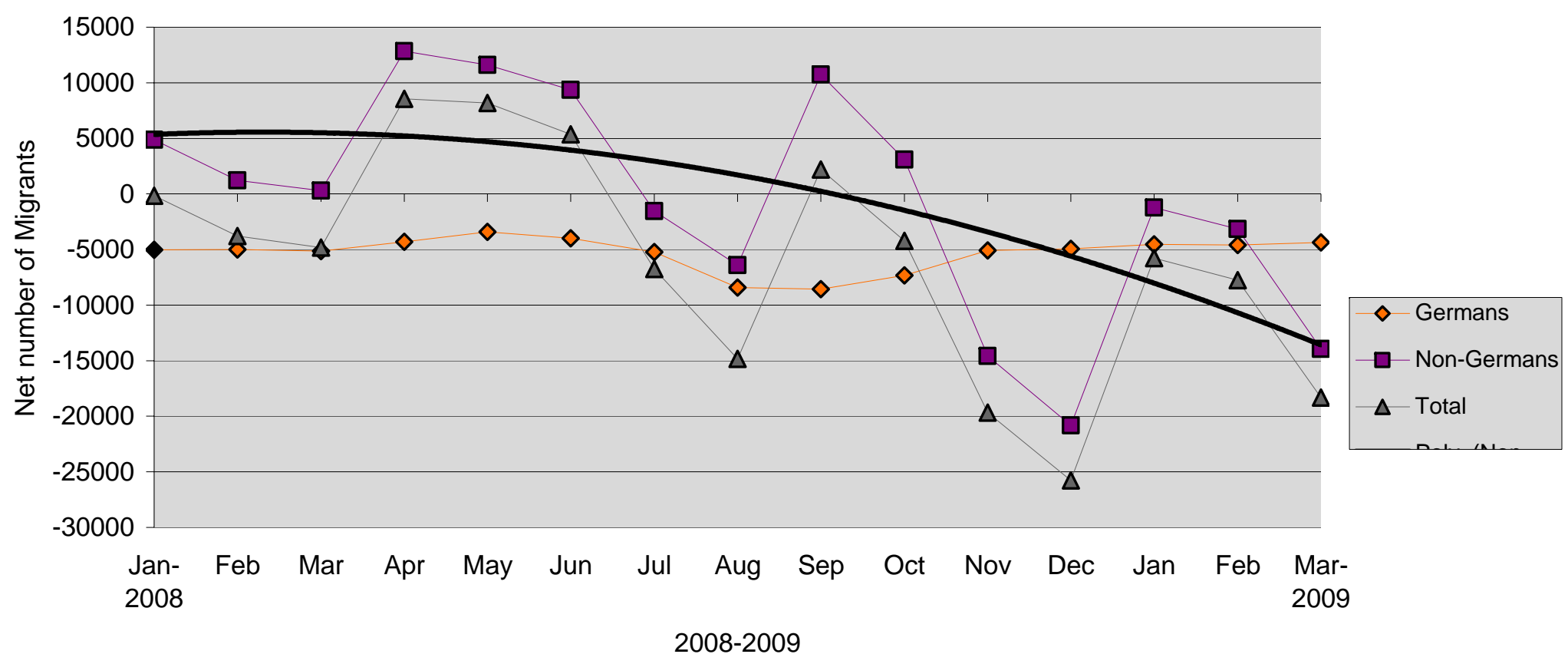

Source: Federal Statistical Office 2009 
Figure 3 Net-migration of foreigners to Germany in the pre-crisis periods

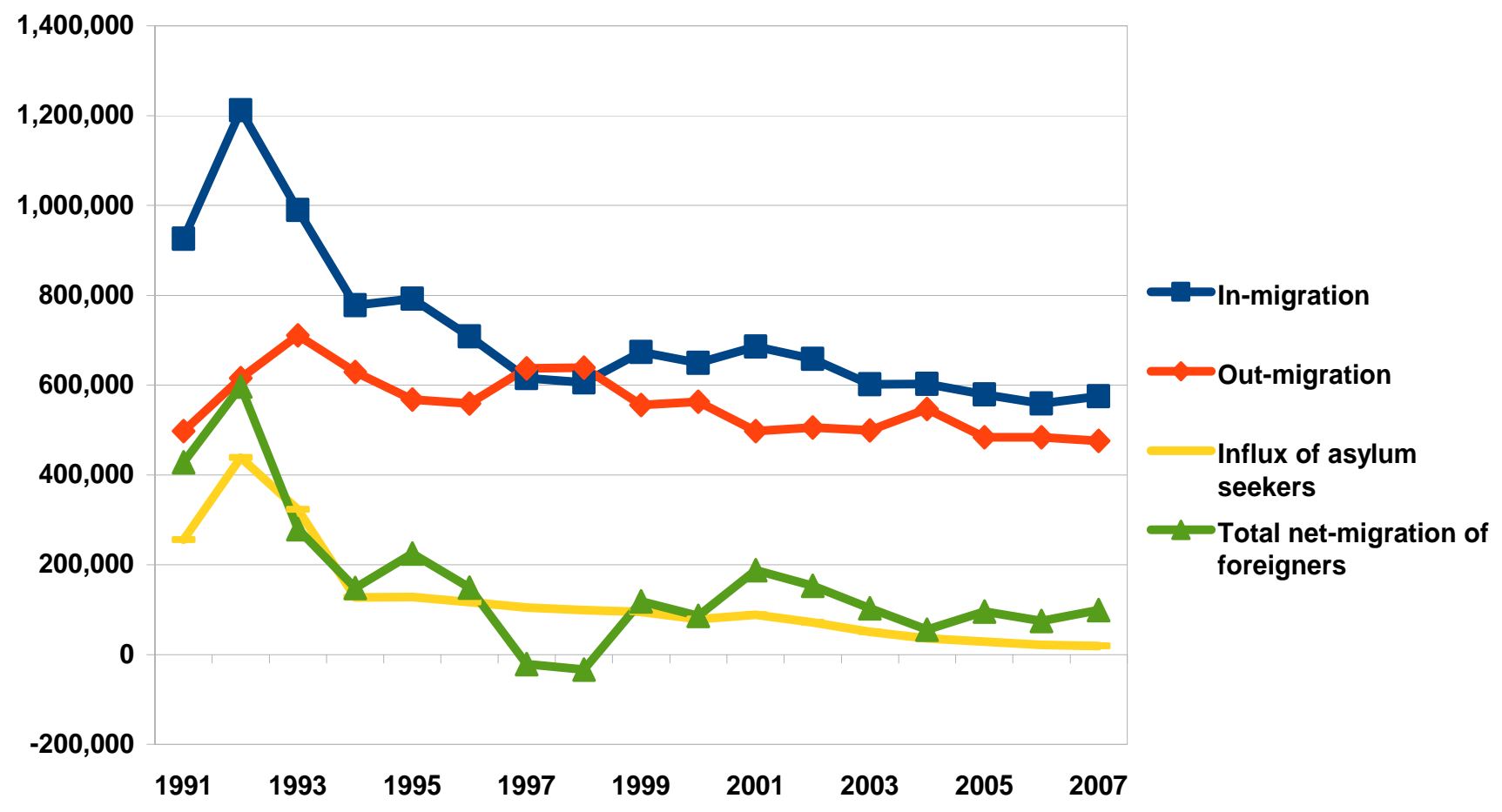

Source: Federal Office for Migration and Refugees 2008 
According to the data up to late 2008, no significant changes have been detected in the volume of migration and remittances towards the start of the recession in 2008. One can only speculate that the growth rates for the year 2009 and 2010 would be lower than the last two years, when the volume of remittance outflow reaches the highest level. However given the stable net-migration development to Germany and a lack of any significant change in the overall (full-time and part-time) employment status of foreign migrants throughout the recession, the likelihood of a substantial decrease in the absolute volume of remittances is low. Another variable that may influence the absolute volume of remittances by migrant workers is the developmental status of the migrants' countries of origin. In a booming sending economy such as that of Turkey, which has been enjoying a high growth rate over the past several years, the demand for remittances from the country of destination, Germany may have been lower. All of these complex conditions make projections for the year 2009 and 2010 difficult, requiring a long-term observation.

Table 6 The flow of remittance from Germany 2000-2008

\begin{tabular}{|c|c|c|}
\hline Workers' re & $\begin{array}{r}\text { ompensation of } \mathrm{e} \\
\text { (ir }\end{array}$ & rant transfers, debit \\
\hline Year & Sum of outflow & Annual growth (\%) \\
\hline 2000 & 7,761 & \\
\hline 2001 & 7,609 & -2.0 \\
\hline 2002 & 9,572 & 25.8 \\
\hline 2003 & 11,190 & 16.9 \\
\hline 2004 & 12,069 & 7.9 \\
\hline 2005 & 12,499 & 3.6 \\
\hline 2006 & 12,454 & -0.4 \\
\hline 2007 & 13,689 & 9.9 \\
\hline 2008 & 14,976 & 9.4 \\
\hline 2009 & & \\
\hline
\end{tabular}

Source: World Bank estimation based on IMF's Balance of Payments Statistics Yearbook 2008 


\section{Economic background: migrant workers during a recession}

As bearer of the largest economy and one of the major foreign labour receiving countries in the EU, the German case is a stark contrast to many other Member States in terms of the effect on the labour market as well as the migrant workforce of the country. Recent labour market analyses of the BA have revealed that the surprisingly stable labour market conditions of Germany during the global and the Eurozone economic downturn. The German economy has demonstrated an earlier and quicker rebound from recession compared to its counterpart in the EU. GDP grew by 0.7 per cent in the third quarter of 2009 compared to the previous quarter, while the growth rate for the Euro zone was 0.5 percent in the same period.

During the recession period, the world's third largest export-economy has experienced a deep decrease in its amount of production in its manufacturing industries. However the workforce of the general economy has remained relatively unaffected by the recession. Most important is the fact that the increase in unemployment has remained at a moderate level throughout the recession period. While unemployment rates of the entire civilian workforce (subject to social security) in the EU-27 have increased by more than two percentage points from the previous year, in Germany they have been limited to an increase of only 0.4 percentage points from 7.1 in the last quarter of 2008 to 7.5 percent in 2009. What is of importance to migration policies is that such moderate labour market and job loss impacts have been similarly applied to the economy's migrant workforce. The rise in unemployment rates among the traditionally low-skilled, service sectorconcentrated migrant workers in the German economy remained only at 0.8 percentage points from 15.8 percent $(427,996)$ to 16.6 percent $(523.603)$, during the same period. 
Figure 4 Unemployment rates among total workforce of Germany

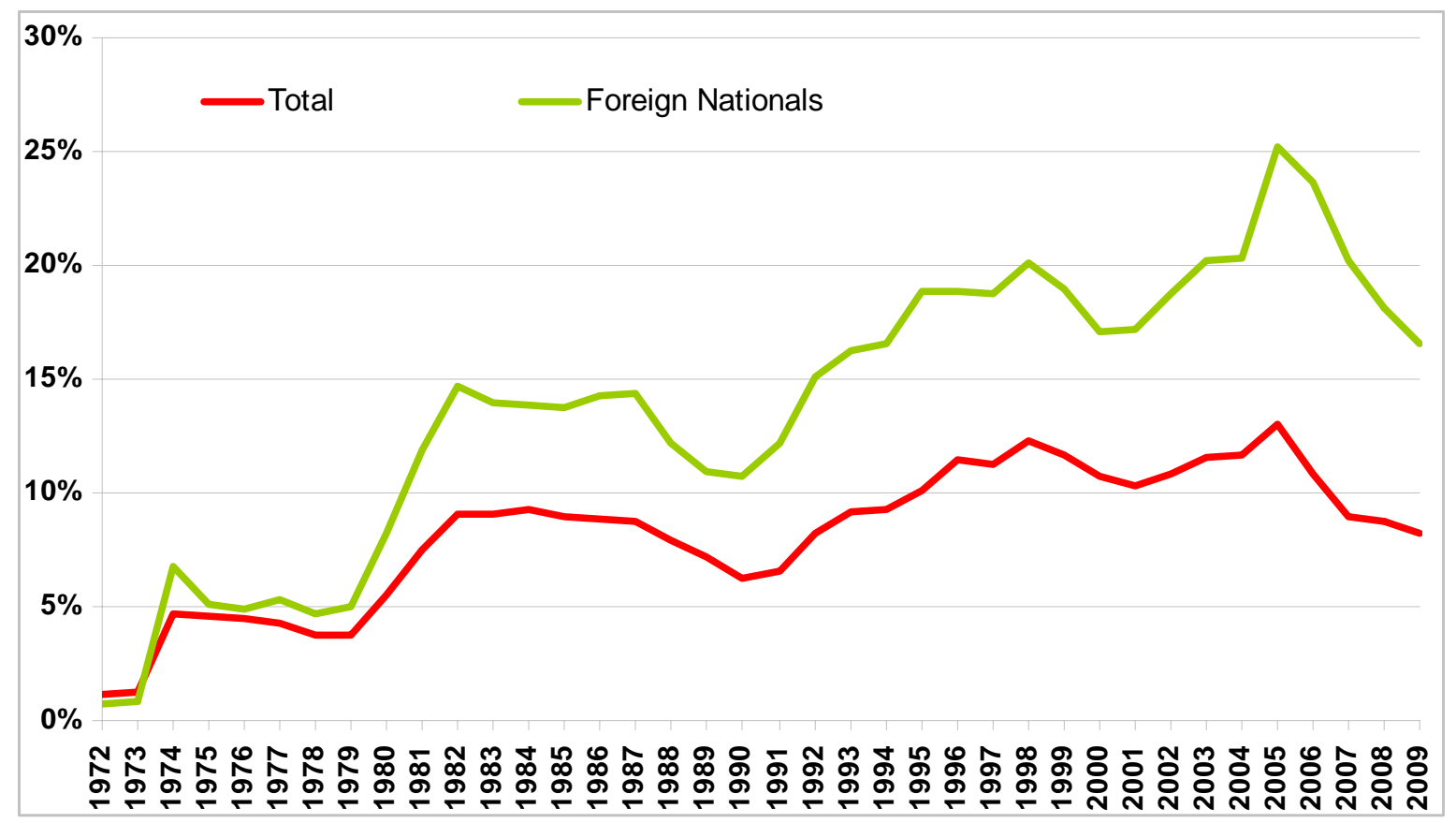

Source: BA (2009c) "Labour market in figures and unemployment statistics" et al IZA labour policy facts \& figures (2009)

The relative stability of the German labour force is largely a result of the government's 'short-time work subsidy scheme', which has been carried out throughout the steepest downturns in the export-economy. Short-time work known as Kurzarbeit in German, means reducing the working hours and salaries of the usual full-time employees in those industries and firms which must struggle to keep their their full-time, and experienced workers during the recession. The government (through the BA) compensates fifty percent of reduced salaries, taking over the social security payments of the employees who work for firms that are qualified to take part in the Kurzarbeit scheme.

Currently, 63.980 firms are covered by the state's stimulus package programme which is operated in the framework of the Social Security Code III or SGB III in German - a contributory form of unemployment benefits. This allows the crisis-affected industries to keep nearly 900.000 workers (BA 2009c). Individuals in employment under the scheme make up 5. 2 percent of the total civilian workforce of the economy. This is an increase of 4.2 percent over the previous year (BA 2009c). 
Although foreign employees are equally entitled to take part in the programme, the BA provides no specific statistics about the foreign migrant workforce. This can be explained by the administrative operation of the short-time work scheme, under which the SGB III benefits are not offered directly to individual employees, but to firms. In these cases, personal details, such as the nationality of individual workforce members are not collected. Yet the workforce in the manufacturing industry have the largest share out of the total short-time work benefits recipients during the crisis, which, according to the latest statistics of the BA (BA 2009c), accounts for 76 percent. One can thus assume that the share of foreign workforce in the short-time working scheme is rather minor. In sum, the coverage of the short-time work scheme has to do with sector rather than nationality of the workforce.

It has been widely argued that the stability of the German labour market, often hailed as the "German jobs miracle” (Krugman 2009), has been largely possible through the German state's stimulus package programme. The German government's subsidised stimulus package is believed to have played a crucial role in maintaining the pre-crisis volume of workforce in the labour market. It was widely applauded at both the national and international level. However, it must be noted that in this case the effect of the global financial crisis was limited to the "crisis of export" that has primarily affected the country's large firms rather than individual workers (see Zimmermann 2009b). A clear division of sectors in the intensity of the effects of the crisis on the economy also explains why the rise in unemployment was concentrated in the medium and high-skill level native-work force. There was a reliance on manufacturing industries during the recession, where unemployment rose by a record figure of 53.7 percent compared to the previous year (BA 2009). Indeed, the short-time work programme is primarily designed to save the long-term, full-time, and largely skilled employees (e.g., technicians, and engineers) in the economy's high-value manufacturing industries. These include metal production, engineering, electrical manufacturing, and automobile industry - which have been most heavily hit in the recent global economic downturn, and consequently have high share in the short-time work scheme that is over 25 percent on average. What is sociodemographically important is that these Germany industries are traditionally strong and 
dominated by a native, male workforce: 91.8 percent of workers in the manufacturing industries are native Germans with over 80 percent being men (calculated from the statistics of BA 2009).

The high growth rates of unemployment in the manufacturing industries during the recession makes a sharp contrast to the level of unemployment rise in the service and domestic industry sectors that are traditionally dominated by vulnerable workforce groups such as foreign migrants. Those labour-intensive, and migrant and female workforce concentrated tertiary industry sectors have experienced a relatively minor increase of unemployment which was recorded at 4.7 per cent in the same period (BA 2009). In turn, the targeted group of the German stimulus package programme happens to be the native workforce, who are concentrated in the most crisis-affected sectors, and consequently most widely benefited by the governments-subsidised job protection programme.

Yet, despite the massive gap across the sectors in terms of the level of effects of current financial crisis, the total unemployment growth rates among the foreign workers during what is considered to be the peak period of the European recession (October 2008October 2009) was slightly higher than that of the native workforce, which were 8 per cent and 7.6 per cent respectively. In sum, a relatively subdued effect of the crisis on the foreign migrant population seems to be a matter of chance rather than a result of a good labour market integration of foreigners. The current global crisis and recession in the German economy have most heavily hit the skill-intensive manufacturing sectors, thus leaving the vast majority of the country's foreign migrant workforce in the most labourintensive and low-waged service industries unaffected. 


\section{Integration Measures: Implications for the labour market integration}

It has been widely believed that actions for integration in most of the Member States have been battered by the economic crisis. This also implies a presumed growth of antiimmigration sentiment and hatred against migrants in the receiving societies. From the labour market perspective, integration measurers have particularly important and farreaching policy implications since the conditions that lead to labour market exclusion entail a broader marginalisation of minority individuals in the host society.

According to the MIPEX- Migrant Integration Policy Index (2006) that provides a comprehensive assessment on integration policies for Third-country nationals in Europe, “integration rests on the concept of 'equal opportunities' for all in both social and civic terms. In socio-economic terms, migrants must have equal opportunities to lead just as dignified, independent and active lives as the rest of the population. In civic terms, all residents can commit themselves to mutual rights and responsibilities on the basis of equality” (MIPEX 2007:4).

Given the multifaceted nature of the migrants' exclusion from the labour market, it is particularly important to consider the scope and limitation of the German nondiscrimination law for the ethnic minority group. Germany's failure to meet the May $1^{\text {st }}$, 2004 deadline to transpose the European Union's anti-discrimination law which is officially known as the EU 'Racial Equality Directives', into its national law is one of the few publicly known and minor examples of the country's battle over policies of equal opportunities and diversity management.

One of the most salient features of the German General Equal Treatment Act (Allgemeines Gleichbehandlungsgesetz or AGG in German) is that the law does not cover discrimination against those of national minorities. Consequently, it has limited effects on ensuring equal opportunities for ethno and national minority migrants and their pathways to the labour market, as shown by the very low level of labour market accessibility, and low participation rates among non-EU national migrant settlers. Another persistent and 
major problem that hampers the labour market access of migrants in Germany is known as "lacking recognition of foreign qualifications". The MIPEX's measurement of integration policies for migrants in Europe demonstrates particularly unfavourable conditions in Germany for labour market access and equality policies against the discrimination of minority migrants. Each policy dimension scored 50 percent of a total 100 percent performance, showing a large gap as compared to some of the most diverse and liberal immigration economies of the EU such as the UK and Sweden.

The German approach to equality policies provides a sharp contrast to the nondiscrimination legislations practised in the Anglo-American immigration systems where diversity management is a key element of equal opportunity policies. In the latter case, a variety of legislations are practised not only to protect exclusion but also to actively promote inclusion of ethnic and national minority workers in every aspect of employment. For example the UK’s 'Race Relations Act' that incorporates the European Union Racial Equality Directives. These directives have a statutory definition of direct and indirect discrimination and harassment against anyone on the grounds of nationality including citizenship apart from race and colour, while all public job announcements include a note on the equal opportunity employer principle that encourages applicants from ethnic minority backgrounds.

Similarly the United States has the Equal Employment Opportunity Commission (EEO) that rules federal laws to protect all manner of vulnerable workers including people of ethnic and national minority origin. The US Department of Justice also runs a special counsel for so-called 'Immigration-Related Unfair Employment Practices'. Diversity management is secured by multiple equality-related legislative systems in the established immigration nations, which are missing in Germany.

It is important to note that the German AGG's is practised by the 'prevention' principle of overt forms of discrimination and harassment that focuses on the traditionally marginalised groups of the society - women and elderly - rather than the 'promotion' of diversity. Indeed, both the prevention-focused non-discrimination law and the Hartz- 
reform 2005 - an act carried out to modernise the labour market and social security policies of the German welfare system - remain to prioritise counteracting ageism and sexism. In consequence, both legislations have a relatively limited influence on the active inclusion of the ethnic and national minority workforce.

Since the German equality law does not have specify and mandate nationality-related discrimination and equal employment opportunity policies, German employers are particularly encouraged to support foreign applications leading to limited recruitment of a non-German and non-EU workforce. To boost labour market participation of the minority, and third-country national migrant workforce in the country, the present AGG law should enhance its diversity management element. Furthermore, a revised law should include and improve work permission-related regulations of the national immigration law for both ethnic and national minorities.

\section{Migration policy responses in the crisis}

Despite the strong anti-immigration position of the conservative party that has been traditionally powerful in the German politics, the current centre-right government has been active to revise immigration-related legislations. The aim of such active approach has been managing quality immigration that the ageing knowledge economy needs in order to sustain its development. Such concern is clearly beyond the capabilities of current economic downturn.

The former guest-worker importing country is seeking long-term strategies to manage skilled migration instead of a short-term response to its existing low-skilled migrant settlers. This is well supported by the major policy changes announced by the Federal Ministry of Labour, and Social Affairs between 2008 and 2009. In May 2009, the German government called for "action to ensure to bring the best brains into the German labour market” which later turned into the new law known as Labour Migration Control Act (Federal Ministry for Labour and Social Affairs 2009b). 
According to the new Labour Migration Control Act (hereafter LMCA), which works in line with the German immigration law (Zunwanderungsgesetz), highly qualified workers from the new member states (EU-12) and third countries have the right to seek permanent residency (Niederlassungserlaubnis) in Germany, under certain conditions required by the immigration authority. Such conditions include a professional position offered by the German employer with the minimum annual salary of 66,000 euro.

Under the article 19 of the revised immigration legislation for highly skilled foreign workers (Auftenthaltsgenemigung fuer Hochqualifizierte), the qualified foreign applicant can also bring their family members into the country. This was not possible in the earlier German foreign labour migration policies such as the green-card agenda that the Social Democratic (SPD) government ambitiously initiated in 2000. This practically ended in 2003 due to its failing approach to meet the long-term needs of the highly skilled foreign workers in the country's IT industry from third countries.

Yet the policy movement towards a liberal, immigration economy that attracts skilled labour appears to be volatile. The German government announced amidst the recession that it will extend restrictions on the free mobility of workers from EU-12 new member states further until year 2011 (Federal Ministry for Labour and Social Affairs 2009b). This is seen as problematic, since a prolonged control over the free movement of workers from the new member states is inconsistent with the state's recent commitment to ease the immigration of highly skilled international migrant workers to the country as delineated in the regulations of the LMCA (Kahanec and Zimmermann 2009). On the other hand, this could be due to the fact that the German government is wary of the potential for an extended influx of unskilled but costly workforce rather than highly skilled workers from the transition economies, which was the case when the government opened the door for return migration of ethnic Germans, and refugees from the formerSoviet Union in the 1990s.

In sum, none of the current immigration policies of the German government appears to be targeting the recent economic crisis. Instead the German government has recently revised legislations to better manage foreign economic migrants which are targeted towards the 
sustainable development of an aged knowledge economy. This will require long-term observations in order to evaluate its impacts on the economy and the migrant populations of the society.

\section{Conclusion}

The analysis of the recent labour market performance and the integration measurers in Germany shows a stark contrast to other member states that are heavily affected by the current crisis and have taken actions to restrict influx of foreign labour migration. Some countries have even decided to repatriate any remaining unemployed migrant workers to their home countries, as a presumably fast-track instrument to help their declining economies.

Uneven macroeconomic developments and foreign labour migration histories among the member economies of the enlarged EU appear to have divergent consequences of the current economic crisis on migrants and migrant policies in the member state of the EU. The current recession is particularly sensitive to sectors. The German experience demonstrates a substantial disparity in terms of the level of labour market impacts on its workforce between the high-value added export-manufacturing and non-manufacturing, tertiary sectors. Indeed the disparity between macroeconomic structures of the member states and, a subsequent gap in the labour market stability across the economies of the EU seem to have a profound influence on the status of the migrant workforce as well as migration policy responses. Recent German experience well proves this well: despite its long practice of restrictive and passive approaches to foreign migration, labour migration from the EU-10 countries to the economy have continued to increase and the migrant workforce in recent economic downturn has remained largely unaffected. 


\section{Future policy implications at the national and the EU level}

Despite the upswing signs of the export-economy that were drawn amid the recession, findings of this study are to be tentative. This owes to the essentially precarious future of the global economic development over the next coming months and years as well as the unexpected subsequent responses of migrant workers to them. However what is more difficult to speculate upon the potential responses of migrants towards changing conditions of the labour market that include the host economy's policies on foreign workforce.

Experts on the German national labour market have continued to predict that the current upswing of the economy can turn into a negative development of its labour market in the coming years (Just et al. 2009, BA, 2010, Zimmermann, 2009). One of the most trickiest and most uncertain issues for the post-crisis German labour market appears to be the potentially detrimental consequences of the state's major stimulus package- short-time work scheme - which the German government has recently decided to extend for another two years (Federal Ministry for Labour and Social Affaires 2009c). Indeed, concerns over deepening productivity decline through the prolonged practice of the short-time labour of millions of workers and the increasing costs of the state are growing (Schneider 2009. et al. Zimmermann 2009). An underlying risk is protecting jobs that are not viable in the post-crisis, recovered economy that can in the long turn interrupt the natural flow of labour from marginal to high-productivity jobs (Pignal, Schaefer 2010). In the end, this may have a counter-impact on the German government's currently liberalising policy to attract highly skilled foreign migrants. Nonetheless, given the limited time of the investigation, and the far more intricate and tardier integration process of the foreign migrant workforce into the labour market of the host economy, it would be impetuous to provide a clear-cut assessment of the state's policies on foreign labour migration in the recession.

Indeed, the mechanism of labour migration development is far more complex than the economic development process itself. Human movement is not always directed towards 
materially better-off places. In contrast, the migration of human agency involves multiple decision-making processes that are much more complex and slower to react to an external shock unlike the mobility of goods and capital. The foremost examples are unnoticed change in the flow of remittances, and (self-motivated) return migration to the migrants' countries of origin over the past one-and-a-half years; these are most evident in less crisis-affected macroeconomies such as Germany, even without well-established integration measures. In a similar sense, regardless of the skill-level, migrant populations that are relatively old and have long-term residency status tend to be less sensitive to short-term economic downturns, and consequently much tardier, as is the case of migrant settlers in Germany.

Yet for Germany, the non-crisis effect on migrants does not mean less work. The country is faced with the more demanding challenge of tackling the wide gaps in employment and social cohesion that have prevailed for decades between the ethno-national minority migrant, and the native population, and which affect the everyday life of the minority members of the society.

What remains most vital beyond the current economic crisis for most of the previously low-skilled temporary-worker only receiving economies of the EU is to develop more efficient strategies that will bring positive consequences over the long-term. Germany, which faces the double challenges of counteracting the long-lasting marginalisation of its ethnic minority population, and attracting more skilled foreign workers, will have to make further reforms in its existing immigration and equality policies. This means constructing a more liberal, diversity-valued socio-legal system that attracts the highly skilled foreign workforce that the aged knowledge economy has long sought after.

We have seen the detrimental consequences of the early German guest-worker politics, which stuck rigidly to the employer- and demand-driven low-skilled migration system. The guest-worker recruiting system which offered little long-term and future prospects to the migrants in the host society resulted in today's deep division between the troubled foreigners and the ordinary citizens (Germans) in German society as well as the German 
public's dominant scepticism regarding any kind of foreign migration into the country among the public.

The German challenges may indeed be a common challenge to the future of the most of the old and emerging guest worker receiving countries of Western and Eastern Europe. This further underscores the need for more active and continued efforts from all Member States to reach the migration-related goals of the ambitious Lisbon agenda. Sustainable development of knowledge-based economy and global competitiveness cannot be achieved without effective utilisation of a diverse workforce.

\section{Acknowledgement}

This paper is an amended version of the country report on Germany that the author provided for the IOM (International Organisation for Migration)-EC (DG Employment, Social Affairs and Equal Opportunities) funded publication project in 2009, "Study on Migration and the Economic Crisis: Implications for Policy in the European Union”. 


\section{References}

Alt, H (2007) Diversity Strategie der Bundesagentur, In nationaler Integraionsplan, Arbeitsgruppe 3"Gute Buildung und Ausbildung sichern-Arbeitsmarktchangen erhoeren"(Diversity strategy of the Federal Agency, in national integration scheme and labour group 3: securing a good education and training to enhance chances in the labour market), Dokumentation der Beratungsprozesses, Berlin, pp. 167-169

BA (Bundesagentur fuer Arbeit: The Federal Agency for Employment) 2009a: Monthly Reports: September, November, and December 2009b: Report on the labour market 2008-2009: a year of crisis for the German labour market 2009c: "Labour market in figures and unemployment statistics". 2010: The labour market in December, and the year of 2009 available at All the data are available at: www.pub.arbeitsagentur.de

Barber, T (2010) “EU summit to plan 10 years of growth”, FT (Financial Times), January 6. 2010

Brubaker, R (1992) Citizenship and nationhood in France and Germany, Cambridge M.A: Harvard University Press

Brussig M, Dittmar V, Knuth M (2009), IAQ (INSTITUTE FOR WORK, SKILLS AND TRAINING)-Report, "VERSCHENKTE POTENZIALE "FEHLENDE ANERKENNUNG VON QUALIFIKATIONSABSCHLUESSEN ERSCHWERT DIE ERWERBSINTEGRATION VON ALG IIBEZIEHER/INNEN MIT MIGRATIONSHINTERGRUND”

Central registrar of foreigners (Auslaenderzentralregister), 2006, 2009 (also available in the Federal Statistical Office database: http://www.destatis.de)

Cornelius, W.A., Tsuda, T., Marin, P.L. and Hollifield, J.F. (2004) Controlling Immigration: a global perspective. $2^{\text {nd }}$ ed. California: Stanford University Press

Eurostat (2008) Population and Social Conditions, Statistics in Focus 98/2008: www.http://epp.eurostat.ec.europa.eu/cache/ITY_OFFPUB/KS-SF-08-072/EN/KS SF-08-072-EN.PDF

European Foundation for the Improvement of Living and Working conditions (2009) "Equality and Diversity in jobs and services for migrants in European cities: good practice guide”, available at: http://www.eurofound.europa.eu

Just. T Eds (2009) "German industry: recovery on its way, but capacity utilisation is still low”, Deutsche Bank Research: www.dbresearch.com

Federal Statistical Office of Germany (Statistisches Bundesamt Deutschland), 
Destatis (2009), available at: http://www.destatis.de

Federal Ministry for Labour and Social Affaires (Bundesministerium fuer Arbeit und Soziales), (2009a) "Impacts of the social policy book II on the people from a migration background" (Wirkungen des SGB II auf Personen mit Migrationshintergrund), Research Report No. F 395, November 2009a

2009b: "Beschäftigung ausländischer Arbeitnehmer aus den neuen EU-Mitgliedstaaten und Drittstaaten“(employment of foreign workers from the new EU-member states, and third countries) report on a new regulation released on 15.May 2009: http://www.bmas.de 2009c: "Kurzarbeit verlängert"(short-time work has been extended), press release 20 May 2009:http://www.bmas.de/portal

Focus (2004) "Eine Frage der Ehre” (a question of honesty: a polish cleaner talks about exisitence, work ethics and black wage in the illegal service industry): www.focus.de (retrieved on 19. January 2010)

Kahanec. M, Zimmermann. K.F (2009) EU Labor markets after post-enlargement Migration, Springer, IZA: Heidelberg:

Knuth, M, Brussig, M, Neuffer, S, Dittmar, V, and Mosler B (2009) in The Federal Ministry for Labour, and Social Affaires (Bundesministerium fuer Arbeit und Soziales), "Impacts of the SGB II on the people from a migration background" (Wirkungen des SGB II auf Personen mit Migrationshintergrund), Research Report No. F 395, November 2009

Krugman. P (2009) “Free to Lose”, The New York Times OP-ED, 13 November 2009

The Federal Office for Migration and Refugees (Bundesministerium fuer Migration \& Fluechtinlige):http://www.bamf.de

Mikrozensus (2007): German population census data

Minister of State in the Federal Chancellery Federal Government Commissioner for Migration, Refugees, and Integration (Die Beauftragte der Bundesregierung fuer Migration, Fluechtlinge und Integration): the 7th, 2007 report of the BMFI on the situation of foreigners in Germany

Mini-job center of German statutory pension insurance (2009), III Quartal 2009, “Akutelle Entwickling im Bereich der geringfuegige Beschaeftigung” (recent development of the mini-jobs sector): http://www.minijobzentrale.de/DE/Service/DownloadCenter/6_Berichte_und_Statisti ken/1__uartalsberichte_d__MJZ/2009/PDF-1quartal3,templateId=raw,property=publicationFile.pdf/PDF-1-quartal3.pdf (downloadable at: www.minijobs.de) 
MIPEX (Migrant Integration Policy Index) (2007) British Council and Migration Policy Group, downloadable at: http://www.integrationindex.eu/

OECD (2007) Jobs for Immigrants. (Vol1): Labour market integration in Australia, Denmark, Germany, and Sweden, OECD Publishing: Paris 2009a International Migration Outlook SOPEMI 2009 Special Focus: Managing Labour Migration Beyond the Crisis, OECD Publishing: Paris 2009b Managing highly skilled labour migration: A comparative analysis of migration policies and challenges in OECD countries

Pigna. S, Schaefer. D (2010) "Short-time work carries long-term consequences" in Financial Times, Sunday January 2, 2010

Schneider, H (2010) “Kurzarbeit droht nutlos und teuer zu werden“: short-time work is threatened to be useless and expansive, Handelsblatt, Wednesday, 27. January 2010

Zjednoczenie Polskie w Wielkiej Brytanii (ZPWB: The Federation of Poles in Great Britain): http://www.zpwb.org.uk

Zipfel, F (2009) „Kurzarbeit- ein wichtiges, und flexibles Instrument in der Krise“ (short work is an important, and a flexible instrument in the time of crisis), Deutsche Bank Research, available at: www.dbresearch.de

Zimmermann, K.F (2009) “Am Arbeitsmarkt gut aufgestellt” (the labour market is in a good shape), Bietigheimer Zeitung November 30, 2009 